\title{
ANALISIS PENGARUH BENCANA BANJIR DI JAKARTA TERHADAP RETURN INDEKS SAHAM SEKTORAL YANG TERDAFTAR DI BURSA EFEK INDONESIA PERIODE 2000-2013
}

\author{
Evelyn Natasha \\ Sumani \\ Universitas Katolik Atma Jaya
}

This study aimed to analyze the effect of flood that occurred in Jakarta toward the return of sectoral stock indices listed on the Indonesia Stock Exchange in the period 2000-2013. The hypothesis of this study is that there are significant effect of floods occurred in Jakarta toward the return of sectoral stock indices listed on the Indonesia Stock Exchange in the period 2000-2013.The data used in this study are secondary data, daily closing prices of sectoral indices in 2000 and 2013 were obtained from the library of the Indonesia Stock Exchange. While the analysis is the analysis of time series with GARCH models. The results of this study are that there are significant effect of floods occurred in Jakarta toward the return of sectoral indices, which 4 of the 10 sectors in 2002, 3 sector in 2007, and 2 sector in 2013. The sectors that are affected significantly are the consumer goods sector, property and real estate, finance, and trade, services and investment.

Keywords:

Flood, Stock Return, GARCH Model. 


\section{PENDAHULUAN}

Pasar modal memiliki peran yang semakin besar dalam dunia bisnis. Pasar modal berperan dalam mendorong percepatan aktivitas investasi. Pasar modal juga menyediakan alternatif investasi yang sangat fleksibel bagi para investor. Dalam berinvestasi, seorang investor dihadapkan pada sejumlah alternatif investasi yang dapat dipilih. Selain pilihan investasi pada benda berwujud seperti tanah, pabrik, mesin, emas, dan lainnya, terdapat pula pilihan untuk berinvestasi aset keuangan seperti saham, obligasi, reksadana, deposito, dan lain sebagainya.

Salah satu investasi yang paling sering dipilih oleh investor adalah investasi saham. Untuk mendukung keputusan berinvestasi saham, investor harus menganalisa imbal hasil (return) dan risiko (risk) yang dimiliki oleh saham yang bersangkutan. Umumnya investor mencari saham dengan tingkat return yang tinggi dan risiko yang rendah. Namun hal tersebut memiliki kemungkinan kecil untuk terjadi mengingat return yang tinggi umumnya diikuti oleh risiko yang tinggi pula.

$$
\text { Risiko adalah besarnya }
$$

penyimpangan antara imbal hasil yang diharapkan (expected return) dan imbal hasil aktual (actual return). Terdapat berbagai macam risiko dalam berinvestasi, yaitu systematic risks dan unsystematic risks. Systematic risk atau biasa disebut risiko pasar adalah risiko berkaitan dengan perubahan yang terjadi di pasar secara keseluruhan. Risiko ini terjadi diakibatkan oleh keadaan di luar perusahaan, seperti inflasi, nilai tukar mata uang, tingkat suku bunga, bencana alam, dan sebagainya yang dapat mempengaruhi pasar secara keseluruhan. Sementara unsystematic risks adalah risiko-risiko yang berkaitan dengan kondisi mikro masing-masing perusahaan (Tandelilin, 2010).

Salah satu risiko sistematik diakibatkan oleh bencana alam. Bencana alam berhubungan dengan kondisi alam yang mengalami perubahan dalam seketika, tanpa dapat diduga sebelumnya. Bencana alam dapat terjadi dimana saja dan kapan saja. Di Indonesia, terutama di Jakarta dan sekitarnya, bencana alam yang paling sering terjadi adalah banjir, yang terjadi pada bulanbulan dengan curah hujan yang tinggi, seperti pada bulan Januari dan Februari. Jakarta adalah ibu kota Republik Indonesia, pusat dari segala aktivitas pemerintahan, industri, perdagangan, jasa, dan aktivitasaktivitas penting lainnya. Bencana yang terjadi di Jakarta dapat berpengaruh pada Indonesia secara keseluruhan atau dapat dikatakan pengaruhnya berskala nasional, karena lumpuhnya Jakarta akan melumpuhkan sendi-sendi penting yang dimiliki Indonesia.

Dalam catatan sejarah, sejak tahun 1621 telah terjadi banjir besar di Jakarta, kemudian disusul tahun 1654, 1873 dan tahun 1918 pada zaman kolonial (Agusta, 2013). Pada periode akhir, banjir besar sempat terjadi pada tahun 1979, 1996, 2002, 2007 dan belum lama ini pada awal tahun 2013. Badan Nasional Penanggulangan Bencana (BNPB) menyatakan jumlah resmi korban meninggal yang tercatat selama banjir tahun 2013 di Jakarta adalah 12 orang, sementara 15.447 warga lainnya terpaksa mengungsi.

Dengan mengacu pada tanda-tanda alam, bukan tidak mungkin siklus banjir lima tahunan akan memporak-porandakan tatanan wilayah di ibu kota. Sebenarnya upaya penanggulangan banjir di Jakarta umurnya hampir setua usia kota ini. Pada zaman pemerintah kolonial Belanda, frekuensi banjir datang setiap 20 tahun sekali, kemudian menjadi setiap 10 tahun dan kini 
menjadi setiap 5 tahun (Mania, 2013). Hal ini memang tidak terlepas dari topografi Jakarta yang $40 \%$ wilayahnya berada di bawah permukaan air pasang, perubahan tata guna lahan, munculnya permukiman baru di hulu sungai dan sepanjang sungai, dan dampak perubahan iklim global.

Walaupun kondisi banjir membuat sebagian besar wilayah Jakarta lumpuh, hal sebaliknya justru terjadi di Bursa Efek Indonesia. Indeks Harga Saham Gabungan (IHSG) kembali cetak rekor baru di saat banyak pialang tak masuk kerja karena banjir (Wahyuni dan Ihsan, 2013). Dua hari setelah datangnya banjir, yaitu pada tanggal 18 Januari 2013, IHSG naik 67,1 poin menyusul maraknya aksi beli asing di lantai Bursa Efek Indonesia. Pada hari tersebut, pelaku pasar tercatat melakukan transaksi perdagangan sebanyak 144.633 kali dengan saham berpindah tangan sebanyak 3,987 miliar lembar saham. Harga saham 145 emiten menguat, sementara 91 emiten terpangkas dan harga saham 100 emiten dalam posisi stagnan. Seluruh sektor memperkuat IHSG di perdagangan hari ini. Sektor dengan kenaikan tertinggi yaitu sektor aneka industri yang menguat $3,14 \%$, sektor manufaktur $2,1 \%$ dan industri dasar $1,7 \%$.

IHSG turun-naik bergantian selama 20 tahun berkaitan dengan kejadian banjir di Jakarta. Ketika banjir kecil melanda Jakarta tahun 1994, IHSG dalam tahun yang sama memiliki pola yang menurun hingga akhir tahun. Namun ketika terjadi banjir besar tahun 1996, IHSG justru mengalami penguatan sampai akhir tahun. Siklus naikturunnya IHSG dikaitkan dengan banjir juga terjadi pada tahun-tahun berikutnya. IHSG kembali turun pada 1997 dan menguat lagi di 1999. Begitu juga pada banjir besar di tahun 2002, IHSG turun dan sebaliknya IHSG kembali naik pada 2007. Banjir tahun 2008, IHSG kembali turun.
Atas dasar uraian di atas, penulis ingin mengadakan pengujian lebih lanjut untuk mengidentifikasi apakah terdapat pengaruh bencana banjir di Jakarta terhadap imbal hasil indeks saham sektoral. Penelitian dilakukan dengan menganalisis imbal hasil saham sebelum dan sesudah terjadinya bencana banjir besar yang terjadi di Jakarta pada tahun 2002, 2007, dan 2013. Penelitian ini berjudul "Analisis Pengaruh Bencana Banjir di Jakarta terhadap Return Indeks Saham Sektoral yang terdaftar di Bursa Efek Indonesia periode 2000-2013".

\section{LANDASAN TEORI}

Pada penelitian yang dilakukan sebelumnya, Luo (2012) menganalisa pengaruh gempa bumi 2011 yang terjadi di Jepang pada enam pasar saham terkemuka di dunia, yaitu Tokyo Stock Exchange, New York Stock Exchange, London Stock Exchange, Hongkong Stock Exchange, Toronto Stock Exchange, dan Frankfurt Stock Market. Penelitian yang menggunakan daily average abnormal return, cumulative abnormal return, dan average cumulative abnormal return ini menyimpulkan bahwa reaksi negatif yang ditimbulkan oleh gempa bumi tersebut muncul di keenam pasar saham tersebut, namun pengaruhnya sangat kecil. Melalui statistic t-test, reaksi tersebut tidak signifikan, namun untuk sebagian saham individual, gempa bumi tersebut memberikan pengaruh yang signifikan. Arah pengaruhnya bergantung pada jenis industri dimana perusahaan yang bergerak.

Maierhofer (2011) mengamati reaksi pasar saham terhadap 5 bencana alam terburuk dengan bantuan model GARCH. Ditemukan bahwa setelah tiap bencana alam terjadi, pasar saham akan mengalami penurunan kecil dalam periode yang singkat, kemudian seluruh pasar akan mengalami 
kenaikan. Penjualan akibat panik disebut sebagai penyebab utamanya.

Worthington dan Valadkhani (2004) meneliti pengaruh bencana alam terhadap pasar saham Australia. Penelitian tersebut menggunakan harga saham harian dan accumulation returns dari tahun 1982 hingga 2002 dengan total 42 bencana alam untuk mengukur pengaruhnya. Kesimpulan yang diperoleh adalah dalam berbagai jenis bencana alam, gempa bumi memiliki pengaruh bervariasi terhadap market returns.

Yamori dan Kobayashi (2002) menganalisa pengaruh gempa bumi HanshinAwaji yang melanda Jepang di tahun 1995 terhadap harga saham sektor asuransi di Jepang. Penelitian mereka menggunakan metodologi event study berdasarkan OLS dan dengan membuat portfolio 13 perusahaan asuransi, mereka menghitung daily abnormal returns portfolio tersebut dari hari ke-0 sampai ke-9 setelah gempa bumi terjadi. Hasil penelitian mereka sama dengan penelitian-penelitian yang dilakukan sebelumnya di Amerika Serikat, bahwa perusahaan asuransi dapat memperoleh keuntungan dari permintaan akan produk yang meningkat akibat bencana alam yang terjadi.

Lamb (1995) menemukan respon negatif harga saham pada perusahaanperusahaan asuransi properti yang secara langsung terlibat dalam pembayaran setelah Badai Andrew melanda Florida dan Louisiana di tahun 1992. Sampel yang digunakan adalah 37 perusahaan terbuka asuransi properti. Daily stock returns digunakan untuk menghitung daily abnormal returns dari 10 hari sebelum badai hingga 30 hari setelahnya. Hasil yang diperoleh menyatakan respon harga negatif perusahaan-perusahaan asuransi properti yang langsung menghadapi kerugian. Namun reaksi harga saham tidak diamati pada perusahaan-perusahaan asuransi yang tidak mengalami kerugian.

\section{ANALISIS DAN PEMBAHASAN}

\subsection{Gambaran Umum Objek Penelitian}

Pada penelitian ini penulis menggunakan harga penutupan harian masing-masing sektor yang terdaftar dalam indeks sektoral pada periode tahun 20002013 untuk menguji pengaruh bencana banjir dilihat dari volatilitas return yang diperoleh. Data tahun 2013 yang digunakan adalah harga penutupan harian masing-masing sektor dari bulan Januari hingga Maret. Seluruh data diolah dengan menggunakan software Microsoft Excel dan EViews7 yang diperoleh dari perpustakaan Bursa Efek Indonesia.

Indeks yang menjadi populasi penelitian ini adalah sebanyak 10 indeks, yang merupakan subindeks dari IHSG. Dalam setiap indeks terdapat 3.260 data yang telah diolah. Berikut pada Tabel 1. adalah daftar sektor yang digunakan penulis dalam penelitian : 
Tabel 1.

Indeks Sektoral

\begin{tabular}{|c|l||l||}
\hline \multicolumn{1}{|c|}{ No. } & \multicolumn{1}{|c||}{ Indeks } & \multicolumn{1}{c|}{ Kode } \\
\hline \hline 1 & Indeks Pertanian & AGRI \\
\hline \hline 2 & Indeks Pertambangan & MINING \\
\hline 3 & Indeks Industri Dasar dan Kimia & BASIC-IND \\
\hline \hline 4 & Indeks Aneka Industri & MISC-IND \\
\hline 5 & Indeks Industri Barang Konsumsi & CONSUMER \\
\hline \hline 6 & Indeks Properti dan Real Estate & PROPERTY \\
\hline \hline 7 & Indeks Infrastruktur, Utilitas, dan Transportasi & INFRASTRUC \\
\hline \hline 8 & Indeks Keuangan & FINANCE \\
\hline 9 & Indeks Perdagangan, Jasa, dan Investasi & TRADE \\
\hline \hline 10 & Indeks Manufaktur & MANUFACTUR \\
\hline \multicolumn{2}{|l}{ Sumber www.idx.co.id } \\
\hline
\end{tabular}

Berikut disajikan grafik-grafik pergerakan indeks saham harian masingmasing sektor.

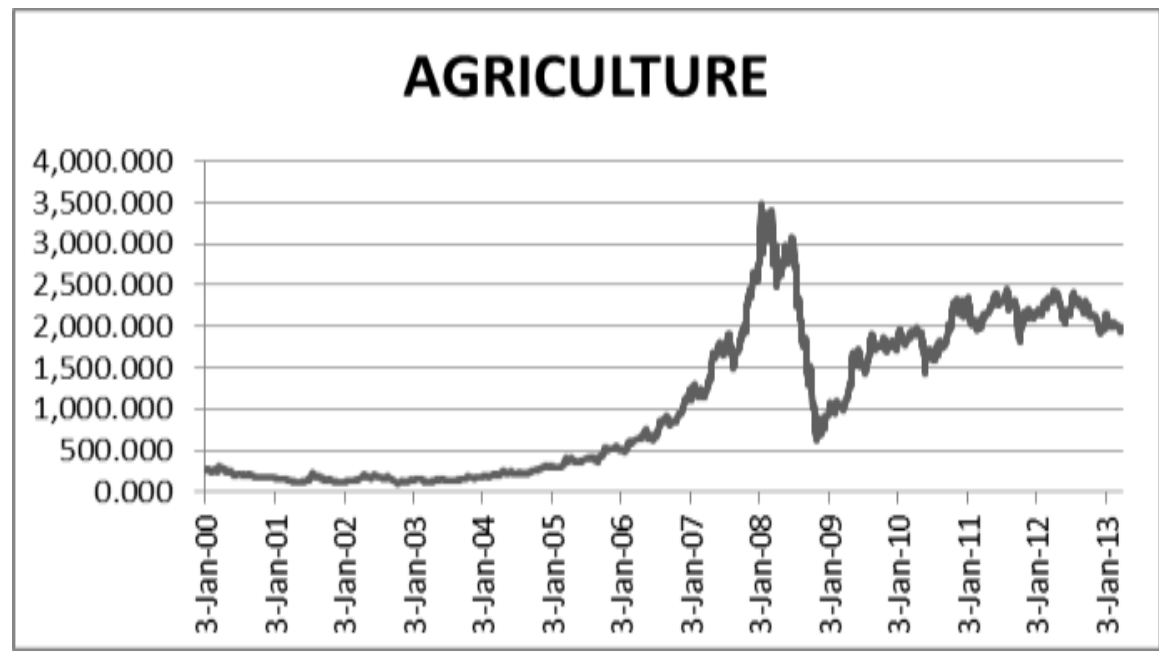

Gambar 1.

Indeks Pertanian

Perusahaan-perusahaan di sektor ini (Gambar 1.) bergerak di bidang pertanian, perkebunan, perikanan, atau peternakan. Sektor ini sangat bergantung pada harga komoditas di luar negri (baik crude palm oil atau jagung). Secara jangka panjang, sektor ini memiliki pertumbuhan yang stabil, karena CPO (crude palm oil) dibutuhkan di seluruh dunia sebagai bahan pangan (minyak goreng) dan biofuel. Indonesia juga merupakan salah satu produsen CPO terbesar di dunia dan merupakan salah satu andalan ekspor Indonesia. Namun penjualan CPO banyak dikontrol oleh pemerintah (dengan adanya pajak ekspor dan sebagainya). Semakin tinggi pajak ekspor, produsen 
cenderung menahan ekspor dan menurunkan target penjualan. Selain itu, CPO juga terpengaruh harga minyak dunia sejak menjadi substitusi minyak (biofuel).

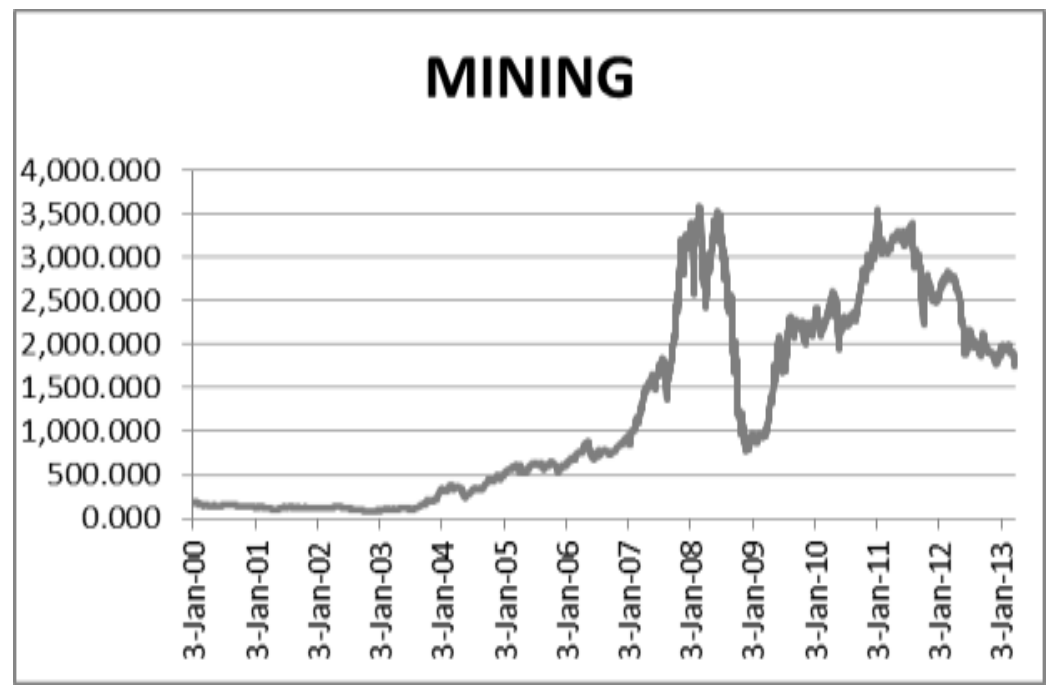

Gambar 2.

Indeks Pertambangan

Sektor ini (Gambar 2.) terdiri dari saham-saham di bidang pertambangan, minyak dan komoditas logam. Sejak tahun 2007, sektor pertambangan menjadi primadona bursa saham Indonesia dengan mencatat pertumbuhan tinggi. Industri ini sangat dipengaruhi harga minyak dunia. Jika harga minyak dunia naik, harga komoditas lain seperti nikel, timah, batubara cenderung ikut menanjak. Pengaruh paling banyak ada di batu bara sebagai substitusi minyak.

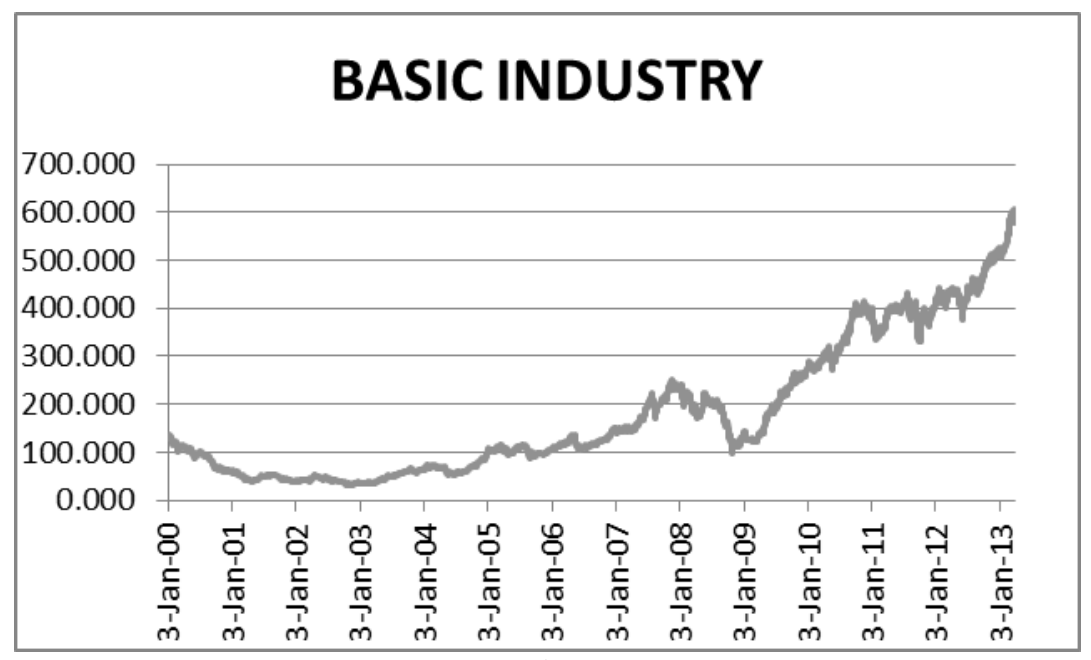

Gambar 3.

Indeks Industri Dasar dan Kimia 
Sektor ini (Gambar 3.) terdiri dari industri hilir, seperti keramik, logam, kimia, plastik dan kemasan, pulp, dan kayu. Karena merupakan industri hilir, saham di sektor ini bergerak secara independen, biasanya terkait dengan ekspansi atau aksi korporasi, saham di sektor ini agak sulit ditebak pergerakannya.

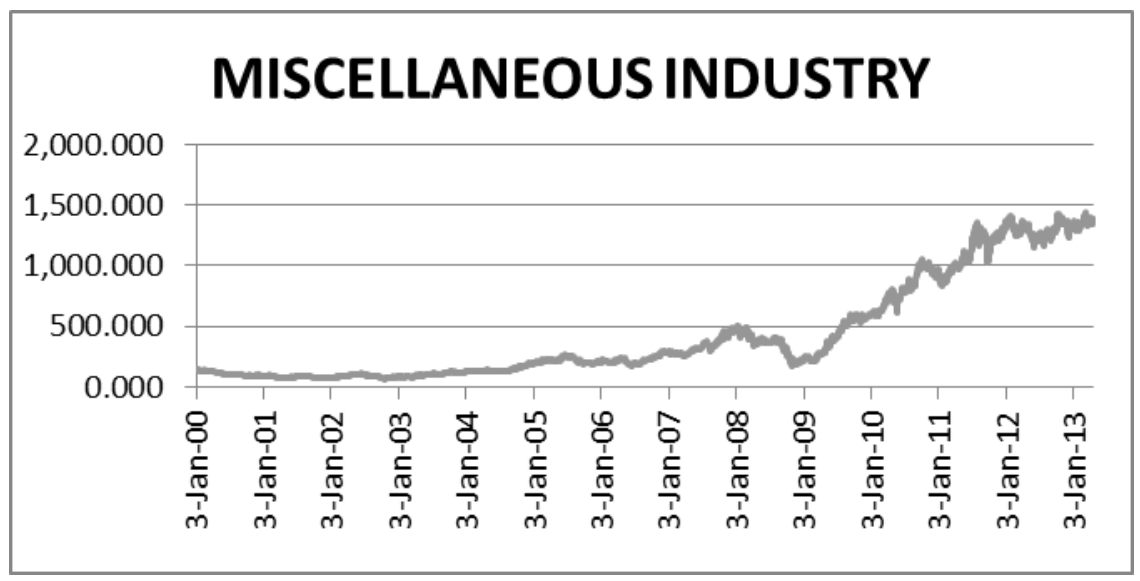

Gambar 4.

Indeks Aneka Industri

Industri yang dominan pada sektor aneka industry (Gambar 4.) adalah otomotif. Lainnya seperti emiten tekstil, elektronik tidak terlalu likuid. Sektor ini sangat bergantung pada bunga bank atau inflasi untuk melakukan ekspansi. Semakin tinggi inflasi dan suku bunga, pertumbuhan penjualan juga menurun. Namun sektor otomotif masih tertolong oleh pertumbuhan penjualan sparepart dan sepeda motor. Dengan masih buruknya layanan kendaraan umum, maka pilihan masyarakat akhirnya juga tetap kembali ke kendaraan pribadi. Selain itu sektor ini juga dipengaruhi oleh nilai tukar rupiah, karena sebagian besar komponen kendaraan bermotor masih diimpor.

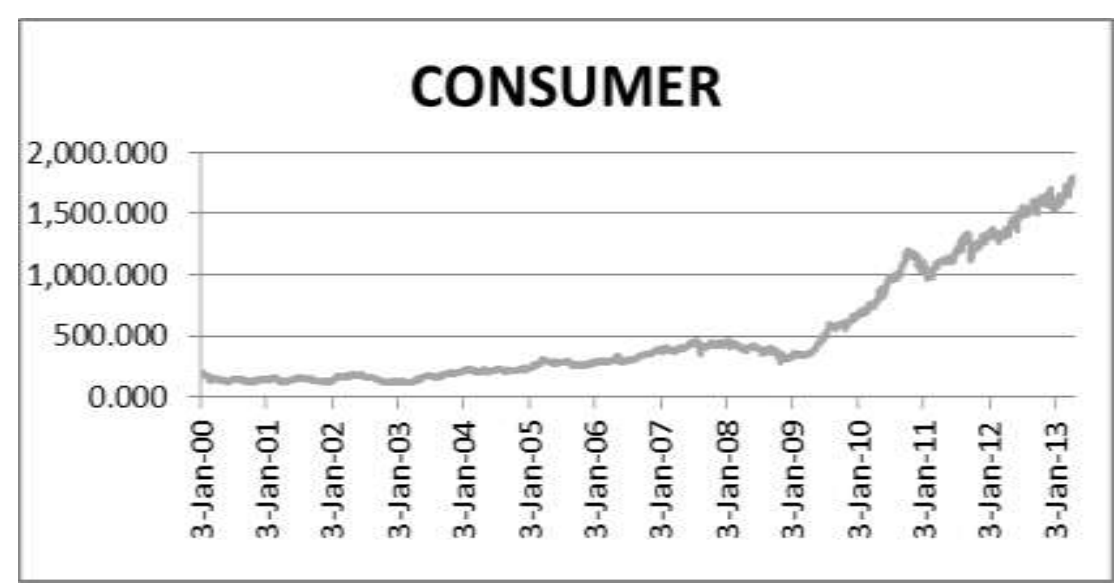

Gambar 5.

Indeks Barang Konsumsi 
Sektor ini (Gambar 5.) adalah industri makanan, minuman, toiletries, dan farmasi. Sektor ini dihuni oleh saham-saham defensif. Produknya dibutuhkan masyarakat. Tidak peduli harga mahal atau tidak orang tetap butuh makan, minum, atau mandi. Jadi saham di sektor ini biasanya tetap bertumbuh walau krisis. Biasanya para investor membeli saham ini untuk diversifikasi risiko. Sahamsaham sektor ini sebagian besar tidak likuid.

Untuk industri farmasi, industri ini sangat dipengaruhi naik-turunnya nilai tukar rupiah, karena bahan baku obat hampir semuanya diimpor, namun emiten-emiten dalam industri ini juga tidak bisa sembarangan menaikkan harga produk yang mereka jual karena hal tersebut dikontrol pemerintah. Sedangkan industri rokok walaupun mendapatkan tantangan dari sisi regulasi pemerintah dan kesehatan, tetap menjanjikan bagi investor karena jumlah perokok di Indonesia yang masih sangat besar.

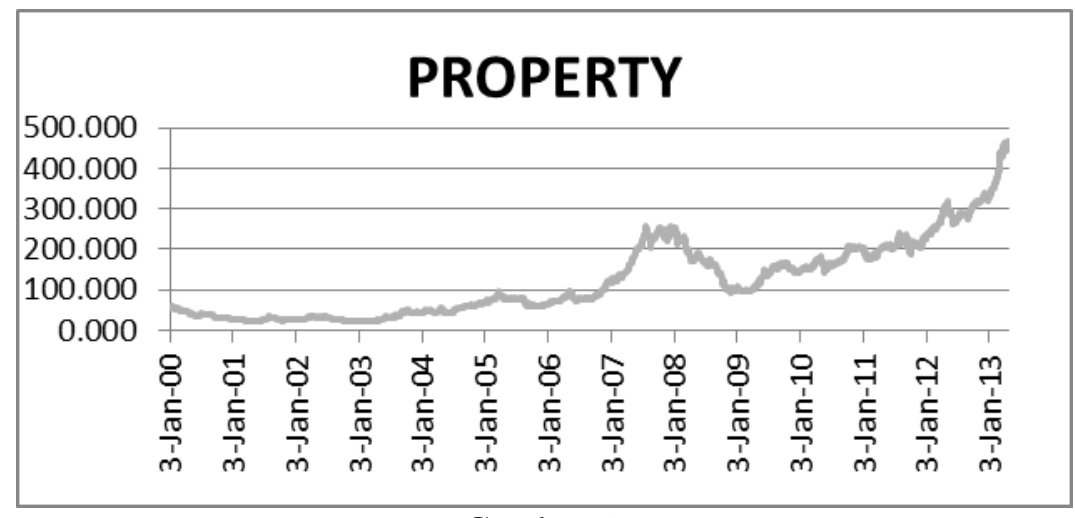

Gambar 6.

Indeks Properti dan Real Estate

Sektor ini (Gambar 6.) sangat bergantung pada kondisi ekonomi. Bila inflasi tinggi, bunga kredit naik, penjualan perumahan juga turun. Sektor ini juga yang paling pertama terkena pengaruh bila suku bunga naik, setelah perbankan.

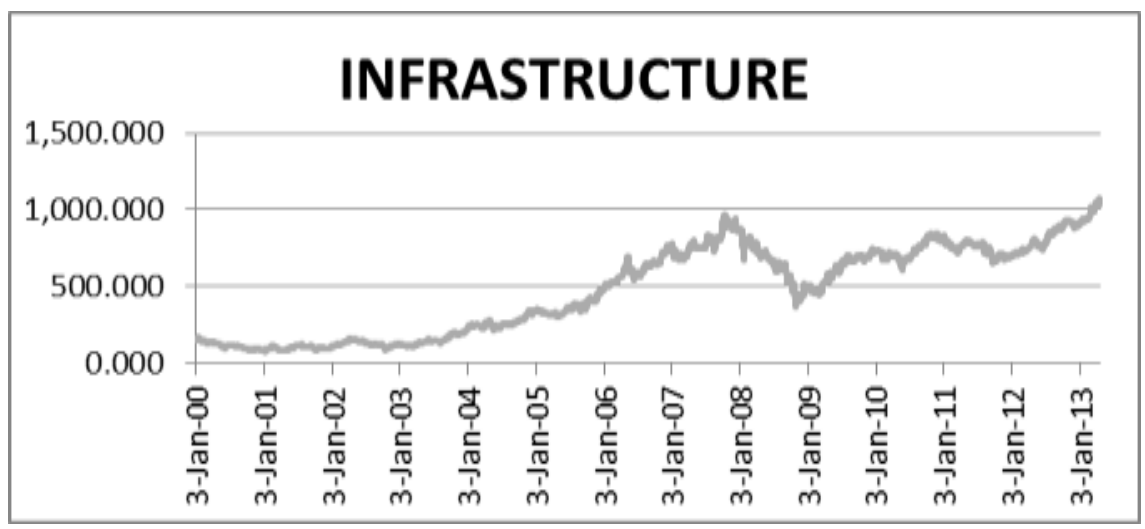

Gambar 7.

Indeks Infrastruktur, Utilitas dan Transportasi 
Sektor ini (Gambar 7.) bergerak dalam bidang pembangunan infrastruktur, jalan, dsb. Sektor ini suka bergerak secara independen, terpengaruh oleh suku bunga dan kucuran dana proyek dari pemerintah.
Secara umum dapat dikatakan sektor ini tahan banting. Di saat krisis bisa menjadi pilihan diversifikasi risiko dan bisa juga menjadi pilihan untuk jangka panjang.

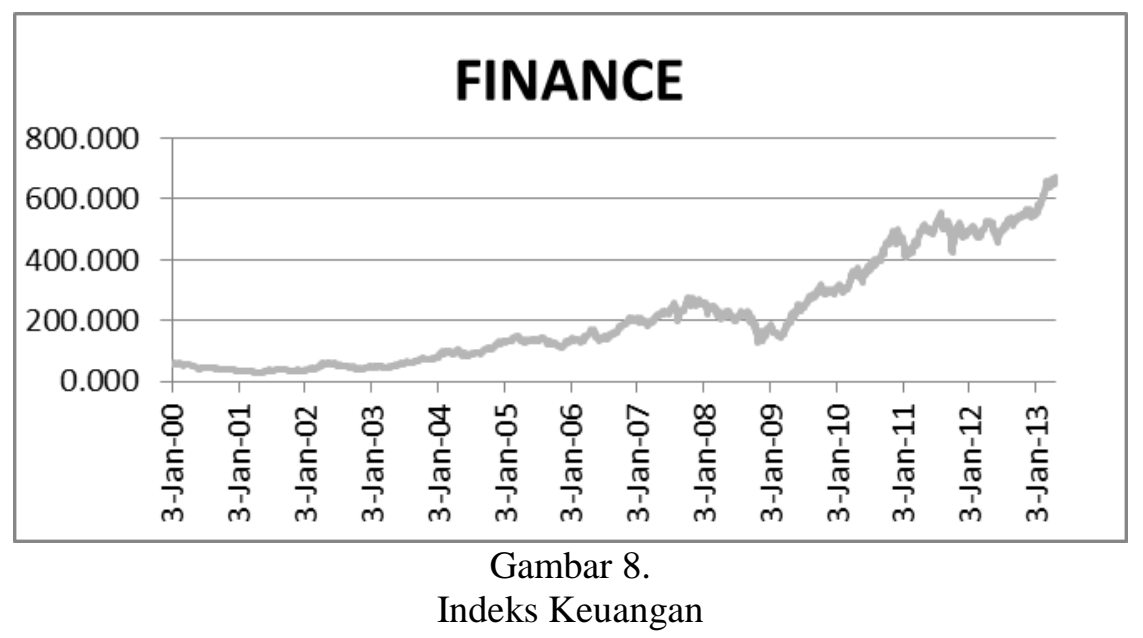

Sektor ini (Gambar 8.) sangat sensitif pada isu ekonomi, suku bunga dan inflasi. Inflasi tinggi akan mengakibatkan daya beli menurun, NPL (non performing loan) naik dan penyaluran kredit terhambat, yang merupakan elemen penting bagi kehidupan bisnis pada sektor ini.

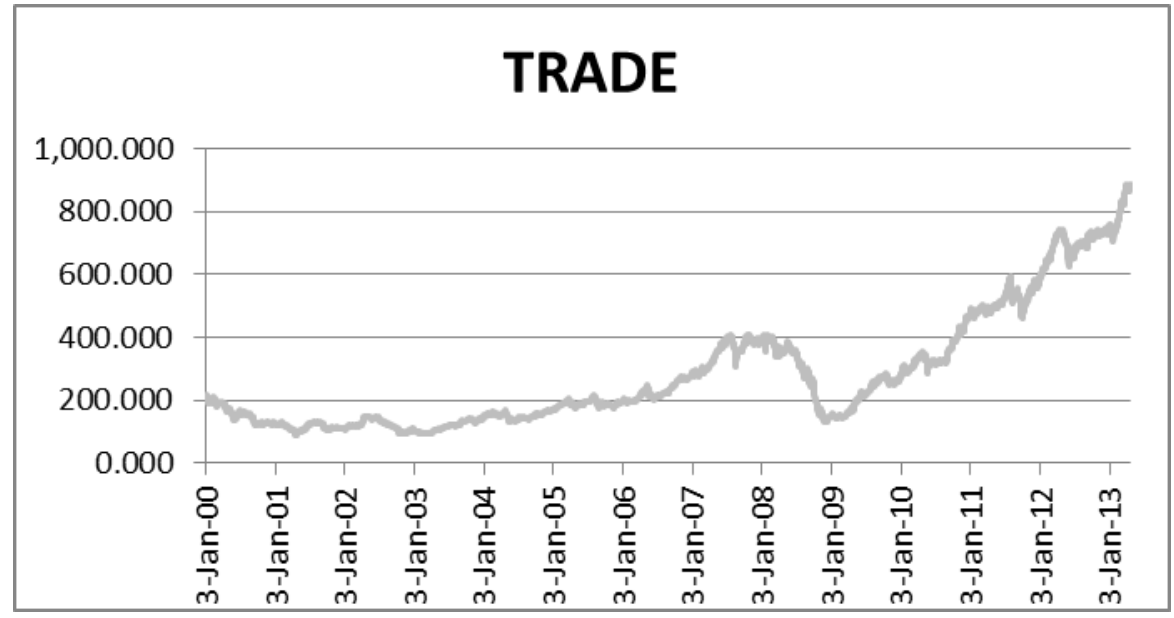

Gambar 9.

Indeks Perdagangan, Jasa, dan Investasi

Sektor ini (Gambar 9.) terdiri dari emiten ritel, distribusi, importir barang produksi, hotel, pariwisata, dan perusahaan investasi. Khusus untuk perusahaan ritel, 
pergerakan pasarnya bergantung pada ekonomi makro dan sifatnya juga musiman. Mendekati hari raya biasanya saham ritel ini naik harganya. Untuk saham lain seperti distribusi, hotel, dll. cenderung bergerak secara independen dan tidak terlalu likuid. Untuk perusahaan investasi pergerakannya lebih banyak karena aksi korporasi atau mengikuti pergerakan anak perusahaannya.

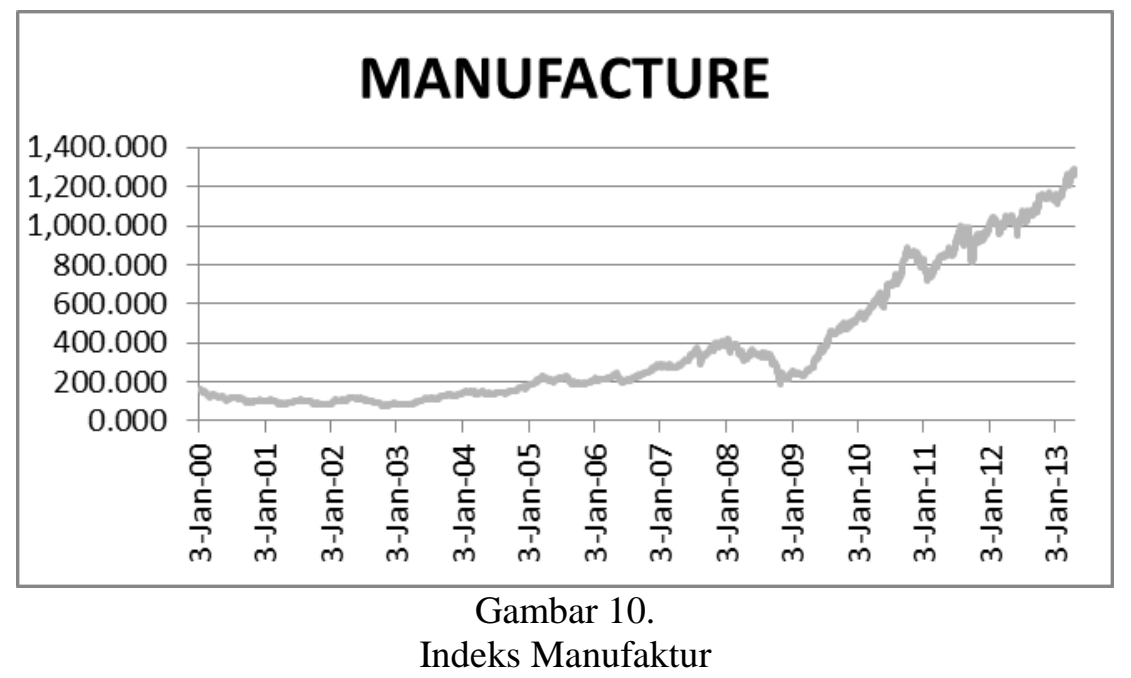

Dari kesepuluh grafik pergerakan indeks harga saham per sektor di atas, terlihat pertumbuhan yang cukup stabil dari tahun 2000 hingga 2007, dan mengalami kenaikan yang cukup besar pada akhir tahun 2007 hingga awal tahun 2008 serta mulai mengalami penurunan pada pertengahan tahun 2008. Namun pada awal tahun 2009 mulai terjadi kenaikan kembali yang cukup tinggi kecuali indeks consumer, kemudian terus menanjak hingga tahun 2013, kecuali indeks pertanian dan pertambangan yang tidak mengalami kenaikan konstan, melainkan berfluktuasi naik-turun.

Penurunan drastis indeks harga saham sektoral pada pertengahan tahun 2008 di atas terjadi karena tingkat inflasi mencapai $12,14 \%$ pada bulan September 2008, sangat tinggi dibandingkan angka inflasi sebesar $6,59 \%$ di bulan Desember 2007 (www.bi.go.id). Mulai pertengahan 2009 hingga tahun 2013, angka inflasi menunjukkan pergerakan yang cukup stabil, dengan kisaran angka 4-5\% tiap bulannya. Hal ini membantu pertumbuhan indeks harga saham yang relatif stabil.

\subsection{Analisis Data}

\subsubsection{Uji Normalitas}

Sebelum dilakukan uji Lagrange Multiplier, terlebih dahulu dilakukan uji Normalitas untuk melihat apakah data berdistribusi normal atau tidak. Hasil yang diperoleh adalah sebagai berikut : 
Tabel 2.

Hasil Uji Normalitas Indeks Pertanian, Industri Dasar, Barang Konsumsi, Keuangan dan Infrastruktur Periode 2000-2013

\begin{tabular}{||c||r||r|r|r|r||}
\hline & \multicolumn{1}{|c|}{ AGRI } & \multicolumn{1}{|c|}{ BASICIND } & \multicolumn{1}{c|}{ CONSUMER } & \multicolumn{1}{c|}{ FINANCE } & \multicolumn{1}{c|}{ INFRAS } \\
\hline \hline Jargue Bera & 4489,18800 & 2699,00300 & 2910,57200 & 1646,45900 & 4035,59400 \\
\hline \hline Probability & 0,00000 & 0,00000 & 0,00000 & 0,00000 & 0,00000 \\
\hline \multicolumn{1}{|l}{ Sumber: Data yang diolah dengan EViews7 }
\end{tabular}

Tabel 3.

Hasil Uji Normalitas Indeks Manufaktur, Pertambangan, Aneka Industri, Properti dan Perdagangan Periode 2000-2013

\begin{tabular}{|c||r||r|r||r||r||}
\hline & \multicolumn{1}{|c|}{ MANU } & \multicolumn{1}{|c|}{ MINING } & \multicolumn{1}{c|}{ MISCIND } & \multicolumn{1}{|c|}{ PROPERTY } & \multicolumn{1}{c|}{ TRADE } \\
\hline \hline Jargue Bera & 4565,61900 & 5406,56900 & 3502,34400 & 3819,83200 & 8361,20300 \\
\hline \hline Probability & 0,00000 & 0,00000 & 0,00000 & 0,00000 & 0,00000 \\
\hline \multicolumn{2}{|l}{ Sumber: Data yang diolah dengan EViews7 }
\end{tabular}

Dari kedua tabel hasil uji Normalitas Jargue Bera di atas terlihat bahwa return masing-masing sektor saham memiliki $p$ value $=0,00000$ yang lebih kecil dari $\alpha=$ 0,05 sehingga $H_{0}$ ditolak dan $H_{1}$ diterima, yang berarti data tidak berdistribusi normal, sehingga dapat dilakukan uji $\mathrm{ARCH}$ Lagrange Multiplier.

\subsubsection{Uji ARCH Lagrange Multiplier}

Setelah dilakukan uji Normalitas, dilakukan uji ARCH Lagrange Multiplier untuk melihat apakah data mengandung unsur heteroskedastis (ARCH effect). Hasil yang diperoleh adalah sebagai berikut :

Tabel 4.

Hasil Uji ARCH Lagrange Multiplier Indeks Pertanian, Industri Dasar, Barang Konsumsi,

Keuangan dan Infrastruktur Periode 2000-2013

\begin{tabular}{|c||r||r|r||r||r||}
\hline LM Test & \multicolumn{1}{|c|}{ AGRI } & \multicolumn{1}{|c|}{ BASICIND } & \multicolumn{1}{c|}{ CONSUMER } & \multicolumn{1}{c|}{ FINANCE } & \multicolumn{1}{c|}{ INFRAS } \\
\hline \hline Obs* R-squared & 66,07899 & 87,10849 & 118,42010 & 224,61070 & 111,22070 \\
\hline \hline Prob chi-squared & 0,00000 & 0,00000 & 0,00000 & 0,00000 & 0,00000 \\
\hline
\end{tabular}

Sumber: Data yang diolah dengan EViews7

Tabel 5.

Hasil Uji ARCH Lagrange Multiplier Indeks Manufaktur, Pertambangan, Aneka Industri, Properti dan Perdagangan Periode 2000-2013

\begin{tabular}{|c||r||r|r|r||r||}
\hline LM Test & \multicolumn{1}{|c|}{ MANU } & \multicolumn{1}{|c|}{ MINING } & \multicolumn{1}{|c|}{ MISCIND } & \multicolumn{1}{|c|}{ PROPERTY } & \multicolumn{1}{c|}{ TRADE } \\
\hline \hline Obs* R-squared & 152,04090 & 59,50224 & 283,42590 & 54,02893 & 32,43392 \\
\hline Prob chi-squared & 0,00000 & 0,00000 & 0,00000 & 0,00000 & 0,00000 \\
\hline
\end{tabular}

Sumber: Data yang diolah dengan EViews7

Dari hasil uji ARCH Lagrange Multiplier di atas terlihat bahwa return masing-masing indeks saham sektoral menghasilkan $p$-value $=0,00000$ yang lebih kecil dari $\alpha=0,05$ sehingga $H_{0}$ ditolak dan
$H_{1}$ diterima, yang berarti seluruh data mengandung unsur heteroskedastis (ARCH effect), sehingga dapat digunakan model GARCH. 


\subsubsection{Estimasi Model GARCH}

Setelah mengetahui bahwa seluruh data mengandung unsur heteroskedastis, maka dilakukan uji GARCH untuk melihat apakah bencana banjir mempengaruhi return indeks sektoral. Dari hasil uji GARCH, diperoleh hasil sebagai berikut :

Tabel 6.

Hasil Uji GARCH Indeks Pertanian, Industri Dasar, Barang Konsumsi, Keuangan dan Infrastruktur Periode 2000-2013

\begin{tabular}{|c|c|c|c|c|c|}
\hline & $\overline{A G R I}$ & BASICIND & CONSUMER & FINANCE & INFRAS \\
\hline \multicolumn{6}{|l|}{ D2002 } \\
\hline Coefficient & 0,001513 & 0,002480 & 0,018500 & 0,015665 & 0,001884 \\
\hline Probability & 0,959600 & 0,702200 & *0,007900 & "*0,016000 & 0,897600 \\
\hline \multicolumn{6}{|l|}{ D2007 } \\
\hline Coefficient & $2-0,001119$ & 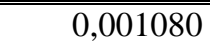 & 0,012677 & $-0,005812$ & $-0,001987$ \\
\hline Probability & 0,969500 & 0,919700 & *0,010600 & 0,335700 & 0,904500 \\
\hline \multicolumn{6}{|l|}{ D2013 } \\
\hline Coefficient & $-0,004582$ & 0,002289 & 0,010743 & 0,001504 & $-0,000620$ \\
\hline Probability & 0,731000 & 0,784800 & $* 0,015000$ & 0,807700 & 0,921000 \\
\hline \multicolumn{6}{|l|}{ Variance equation } \\
\hline RESID $(-1)^{\wedge} 2$ & 0,077626 & 0,147111 & 0,168831 & 0,138717 & 0,159893 \\
\hline Probability & 0,000000 & 0,000000 & 0,000000 & 0,000000 & 0,000000 \\
\hline RESID $(-2)^{\wedge} 2$ & & & & & $-0,092444$ \\
\hline Probability & & & & & 0,000000 \\
\hline GARCH (-1) & 0,914470 & 0,769294 & 0,750587 & 0,812050 & 0,927324 \\
\hline Probability & 0,000000 & 0,000000 & 0,000000 & 0,000000 & 0,000000 \\
\hline R-squared & $-0,001316$ & $-0,001220$ & $-0,000973$ & $-0,001356$ & $-0,001449$ \\
\hline AIC & $-4,875628$ & $-5,493761$ & -5,722763 & $-5,495206$ & $-5,229988$ \\
\hline SC & $-4,864421$ & $-5,482554$ & -5,722763 & $-5,483998$ & $-5,216913$ \\
\hline Log likelihood & 79953,274000 & 8960,831000 & 9352,372000 & 8963,186000 & 8531,881000 \\
\hline \multicolumn{6}{|l|}{ ARCH-LM Test } \\
\hline Obs* R-squared & 1,678063 & 0,265591 & 0,037612 & 0,371382 & 0,086520 \\
\hline Prob chi-squared & 0,195200 & 0,606300 & 0,846200 & 0,542300 & 0,768600 \\
\hline
\end{tabular}

Sumber: Data yang diolah dengan EViews7

Keterangan : D2002 = periode bencana banjir tahun 2002

D2007 = periode bencana banjir tahun 2007

D2013 = periode bencana banjir tahun 2013

* $\quad=$ signifikan terhadap $\alpha=5 \%$ 
Tabel 7.

Hasil Uji GARCH Indeks Manufaktur, Pertambangan, Aneka Industri, Properti dan Perdagangan Periode 2000-2013

\begin{tabular}{|c|c|c|c|c|c|}
\hline & MANU & MINING & "MISCIND & PROPERTY & TRADE \\
\hline \multicolumn{6}{|l|}{ D2002 } \\
\hline Coefficient & 0,006095 & 0,000824 & 0,006718 & $-0,018472$ & $-0,015590$ \\
\hline Probability & 0,451900 & 0,971100 & 0,245800 & $* 0,000000$ & $* 0,021200$ \\
\hline \multicolumn{6}{|l|}{ D2007 } \\
\hline Coefficient & 0,002200 & 0,001716 & 0,002528 & $-0,016225$ & $-0,014179$ \\
\hline Probability & 0,754600 & 0,968400 & 0,621900 & $* 0,000000$ & $* 0,000400$ \\
\hline \multicolumn{6}{|l|}{ D2013 } \\
\hline Coefficient & 0,003442 & -0,004053 & 0,004160 & 0,001576 & $-0,008575$ \\
\hline Probability & 0,562200 & 0,741200 & 0,607700 & 0,843500 & *0,048200 \\
\hline \multicolumn{6}{|l|}{ Variance equation } \\
\hline RESID $(-1)^{\wedge} 2$ & 0,150759 & 0,086864 & 0,178583 & 0,127371 & 0,099756 \\
\hline Probability & 0,000000 & 0,000000 & 0,000000 & 0,000000 & 0,000000 \\
\hline RESID $(-2)^{\wedge} 2$ & & & $-0,128449$ & & \\
\hline Probability & & & 0,000000 & & \\
\hline GARCH (-1) & 0,780718 & 0,898777 & 0,935939 & 0,849013 & 0,875968 \\
\hline Probability & 0,000000 & 0,000000 & 0,000000 & 0,000000 & 0,000000 \\
\hline R-squared & $-0,002184$ & $-0,001728$ & $-0,001821$ & 0,000170 & 0,000906 \\
\hline AIC & $-5,827532$ & $-4,952361$ & $-5,170266$ & $-5,573990$ & $-5,689094$ \\
\hline SC & $-5,816324$ & $-4,941153$ & $-5,157190$ & $-5,562782$ & $-5,677886$ \\
\hline Log likelihood & 9504,877000 & 8078,348000 & 8434,533000 & 9091,603000 & 9279,223000 \\
\hline \multicolumn{6}{|l|}{ ARCH-LM Test } \\
\hline Obs* R-squared & 0,035063 & 0,481950 & 0,080770 & 0,878249 & 0,536221 \\
\hline Prob chi-squared & 0,851500 & 0,487500 & 0,776300 & 0,348700 & 0,464000 \\
\hline
\end{tabular}

Sumber: Data yang diolah dengan EViews7

Keterangan : D2002 = periode bencana banjir tahun 2002

D2007 = periode bencana banjir tahun 2007

D2013 = periode bencana banjir tahun 2013

* $\quad=$ signifikan terhadap $\alpha=5 \%$

Dari hasil pengujian dengan metode GARCH, terlihat bahwa bencana banjir memiliki pengaruh signifikan pada indeks sektor barang konsumsi (consumer) dan sektor perdagangan (trade) pada setiap kali terjadinya banjir, sektor keuangan (finance) hanya di tahun 2002, dan sektor properti pada periode banjir tahun 2002 dan 2007. Hal tersebut ditunjukkan oleh nilai prob yang lebih kecil dari $\alpha=0,05$.
Nilai coefficient dari masing-masing variabel independen tersebut secara umum menunjukkan jenis pengaruh (positif atau negatif) terhadap return indeks saham yang ada. Untuk indeks barang konsumsi dan keuangan, banjir memiliki pengaruh positif, dilihat dari coefficient yang bernilai positif pada saat prob lebih kecil dari $\alpha=0,05$. Sementara terhadap indeks sektor properti 
dan perdagangan, bencana banjir memiliki pengaruh negatif.

Nilai log likelihood pada setiap indeks di atas menunjukkan nilai yang besar, sehingga dapat dikatakan memenuhi kriteria goodness of fit, yang artinya model ini baik untuk penelitian. Nilai prob untuk setiap variance equation juga di bawah $\alpha=0,05$, yang artinya model yang dipilih, yaitu model GARCH, sudah tepat.

Dari hasil pengujian ARCH-LM di atas terlihat bahwa $p$-value yang dihasilkan semuanya lebih besar dari $\alpha=0,05$, yang artinya $\mathrm{H}_{0}$ diterima, yaitu data tidak memiliki unsur heteroskedastis (ARCH Effect) lagi.

\subsection{Pembahasan}

Data penelitian masing-masing sektor sebanyak 3.260 observasi berhasil dikumpulkan harian dari tahun 2000 hingga Maret 2013. Dari pengujian terhadap olahan data yang berhasil dikumpulkan, sebanyak $40 \%$ populasi terpengaruh oleh bencana banjir pada tahun 2002, menurun menjadi $30 \%$ di tahun 2007 , dan hanya $20 \%$ di tahun 2013.

Melalui pengujian GARCH, terlihat bahwa setiap bencana banjir berpengaruh positif terhadap indeks barang konsumsi. Hal ini sesuai dengan hasil penelitian Xie, Guo, dan Dang (2011) yang menyatakan bahwa sektor yang terpengaruh positif oleh bencana alam adalah sektor makanan dan minuman, farmasi, logam, dan material bangunan. Sektor barang konsumsi terdiri dari industri makanan dan minuman, rokok, farmasi, kosmetik dan barang keperluan rumah tangga, dan peralatan rumah tangga.

Saat bencana banjir datang, pemerintah maupun sukarelawan segera mendirikan posko-posko penampungan korban banjir dan membuka banyak kesempatan untuk berdonasi. Donasi yang diberikan paling banyak adalah makanan dan minuman, terutama mie instan. Setelah itu diikuti oleh obat-obatan bagi para korban banjir yang terserang demam, flu, atau penyakit kulit akibat banjir. Selain itu pasca datangnya banjir, banyak keperluan rumah tangga yang perlu diganti. Hal tersebut juga berkontribusi terhadap pengaruh positif pada indeks barang konsumsi.

Selain industri farmasi dan makanan dan minuman, Xie, Guo, dan Dang (2011) juga menyebutkan bahwa sektor logam dan material bangunan terpengaruh positif. Di Indonesia, industri logam masuk ke dalam sektor industri dasar dan kimia.

Industri dasar dan kimia tidak terpengaruh oleh banjir. Industri dasar dan kimia terdiri atas industri semen, keramik, porselen, kaca, logam, kimia, plastik dan kemasan, pakan ternak, kayu dan pengolahan, dan pulp dan kertas. Sebanyak $70 \%$ dari sektor tersebut kegiatan operasional perusahaannya dilakukan di luar Jakarta dan hanya kantor pusatnya saja yang berdomisili di Jakarta. Hal tersebut menjadi alasan mengapa indeks ini tidak terpengaruh.

Sesuai dengan hasil penelitian Yamori dan Kobayashi (2002) yang menyatakan bahwa perusahaan asuransi dapat diuntungkan oleh terjadinya banjir, indeks keuangan yang terdiri dari industri asuransi, perbankan, lembaga pembiayaan, dan perusahaan efek memperoleh pengaruh signifikan yang positif pada bencana banjir tahun 2002.

Hasil di atas berkebalikan dengan hasil penelitian Lamb (1995) yang menemukan respon negatif harga saham pada perusahaan-perusahaan asuransi. Hal ini dikarenakan pada tahun 2002 belum banyak orang di Indonesia yang tertarik untuk mengasuransikan barang-barang berharga mereka. Perusahaan-perusahaan asuransi masih belum diperhatikan. Namun lewat peristiwa banjir ini banyak harta benda yang rusak sehingga membuat orang ramairamai mengasuransikan harta benda mereka, 
terutama mobil dan rumah tinggal. Apalagi setelah mempelajari pola banjir besar. Setelah tahun 1996, kemudian tahun 2002.

Selain lini asuransi, perbankan juga berkontribusi membuat pengaruh positif dari banjir. Banyak orang berbondong-bondong menyimpan seluruh harta berharganya di bank, terutama surat-surat berharga, logam mulia, dan uang. Uang yang disimpan memiliki manfaat besar bagi perusahaan perbankan karena mereka akan memperoleh banyak dana cair yang dapat diputar untuk pemberian kredit.

Selain asuransi dan perbankan, perusahaan-perusahaan pembiayaan juga diuntungkan oleh datangnya banjir, karena salah satu jenis jasa yang ditawarkan adalah operating lease. Jenis pembiayaan ini sangat menguntungkan lessee karena seluruh risiko tetap ditanggung oleh lessor. Melihat kondisi Jakarta yang rawan banjir, hal tersebut sangat menarik minat calon lessee.

Pada tahun-tahun berikutnya yaitu tahun 2007 dan 2013 bencana banjir ternyata tidak berpengaruh terhadap indeks keuangan. Hal ini terjadi karena banjir telah menjadi pola. Tidak semua perusahaan asuransi mau menangani klaim akibat bencana alam. Perusahaan-perusahaan asuransi yang mau menerima klaim akibat bencana alam biasanya memiliki banyak persyaratan yang harus dipenuhi, juga telah meneliti sebelumnya, pada kawasan rawan bencana alam seperti banjir, ditetapkan premi yang lebih tinggi dibanding kawasan bebas banjir sehingga perusahaan tidak akan merugi.

Sesuai dengan hasil studi Xie, Guo, dan Dang (2011) yang menyatakan bahwa sektor pariwisata terpengaruh negatif oleh bencana alam, indeks perdagangan, jasa, dan investasi juga terpengaruh negatif oleh bencana banjir. Indeks ini terdiri dari industri perdagangan barang produksi, perdagangan eceran, restoran, hotel dan pariwisata, periklanan, percetakan, media cetak, jasa komputer dan perangkatnya, dan perusahaan investasi.

Secara keseluruhan indeks ini terpengaruh oleh bencana banjir. Pertama perdagangan barang produksi dan eceran yang pastinya terhambat akibat terjadinya banjir dikarenakan sebagian besar distribusinya dilakukan lewat jalan darat, sementara hampir seluruh jalan darat terkepung banjir. Hal serupa juga dialami oleh industri restoran, hotel, pariwisata, periklanan, media yang kegiatan operasionalnya akan terhambat dengan datangnya banjir. Begitu pula dengan perusahaan investasi yang sebagian besar kegiatan operasionalnya bertumpu pada media komunikasi yaitu telepon dan jaringan internet. Pada cuaca buruk atau curah hujan yang tinggi, sinyal untuk media komunikasi biasanya terhalang.

Selanjutnya yaitu indeks properti dan real estate selama dua periode banjir berturut-turut terpengaruh negatif, yaitu pada tahun 2002 dan 2007. Hal ini terjadi akibat terpukulnya perusahaan-perusahaan properti dan real estate di kawasan-kawasan banjir, seperti pemukiman di kawasan Kelapa Gading, Pluit, Puri, Sunter, Ancol, kawasan perkantoran seperti Sudirman-Thamrin, dan daerah-daerah lain yang tergenang banjir. Namun upaya perusahaan-perusahaan properti ini untuk menghindari banjir nampaknya cukup membuahkan hasil, ditunjukkan di tahun 2013 indeks properti sudah tidak terpengaruh lagi. Hal tersebut disebabkan semakin banyak perusahaan pengembang yang beralih ke hunian apartemen maupun town house yang berlokasi di area bebas banjir juga beralih ke luar Jakarta yang masih aman dari banjir seperti kawasan Sentul, Alam Sutera, Modern Land, Melati Mas, dll.

Sementara untuk indeks-indeks lain yang tidak terpengaruh, hal tersebut terjadi dikarenakan sebagian besar dari perusahaan- 
perusahaan tersebut menjalankan kegiatan operasionalnya di luar Jakarta, hanya kantor pusatnya saja yang berdomisili di Jakarta.

Sementara pada indeks infrastruktur yang seharusnya terpengaruh negatif, pada kenyataannya tidak terpengaruh. Hal tersebut terjadi dikarenakan pada indeks ini yang berpotensi terpengaruh hanya industri komunikasi. Sementara industri lainnya yang termasuk dalam indeks ini seperti energi, jalan tol, pelabuhan, bandara, transportasi, dan konstruksi non bangunan tidak berpotensi terpengaruh. Hal ini disebabkan jalan tol di Jakarta sebagian besar merupakan jalan layang. Emiten yang memiliki nilai kapitalisasi besar pada industri transportasi bergerak di bidang transportasi udara dan laut. Sementara sisanya memiliki alasan sama seperti di atas, yaitu tidak melaksanakan kegiatan operasional di Jakarta.

Penurunan pengaruh bencana banjir dari periode sebelumnya ke periode selanjutnya (dalam penelitian ini yaitu dari $40 \%$ populasi hingga tinggal $20 \%$ ) tidak terlepas dari upaya pemerintah dalam menanggulangi bencana banjir, seperti dibangunnya Banjir Kanal Timur (BKT), operasi pembersihan pemukimanpemukiman liar di pinggiran sungai atau bantaran kali, pembangunan waduk-waduk, pembersihan got, kali, dan sungai dari sampah, dll.

Sesuai dengan hasil penelitian Luo (2012), dapat disimpulkan bahwa pengaruh signifikan dari bencana alam dan arahnya bergantung pada jenis industri dan letak dilaksanakannya kegiatan operasional perusahaan.

\section{KESIMPULAN DAN SARAN}

\subsection{Kesimpulan}

Penelitian ini dilakukan untuk mengetahui apakah bencana banjir di Jakarta pada tahun 2002, 2007, dan 2013 memiliki pengaruh terhadap return harga saham harian indeks sektoral pada periode 2000-2013. Hasil pengujian dengan menggunakan metode GARCH dengan variabel boneka (dummy variable) menunjukkan bahwa :

- Bencana banjir di Jakarta memiliki pengaruh terhadap return indeks sektoral, yaitu sebesar $40 \%$ dari populasi pada tahun 2002, 30\% dari populasi pada tahun 2007, dan 20\% dari populasi pada tahun 2013. Penurunan terpengaruhnya indeks sektoral secara bertahap dari $40 \%$ menjadi $30 \%$ hingga $20 \%$ juga menunjukkan bahwa orang semakin terbiasa dengan bencana banjir, seperti sebuah tradisi kota Jakarta dan semakin pandai dalam 'mengakalinya'. Hal ini juga didukung oleh berbagai upaya pemerintah dalam menanggulangi bencana banjir di Jakarta, sehingga dampak banjir dari periode sebelumnya ke periode selanjutnya pun dapat diminimalisir, sehingga dampaknya pada pasar saham pun berkurang.

- Sektor yang terpengaruh signifikan positif adalah indeks barang konsumsi dan indeks keuangan. Sementara indeks yang terpengaruh signifikan negatif oleh bencana banjir hanya indeks properti dan real estate dan perdagangan, jasa, dan investasi. Indeks properti dan real estate dan perdagangan, jasa, dan investasi terpengaruh negatif akibat timbulnya panic selling atau penjualan karena panik saham industri tersebut akan jatuh akibat banjir. Sementara pada indeks barang konsumsi terjadi lonjakan dikarenakan kebutuhan mendesak akan barang-barang yang diproduksi oleh sektor industri tersebut. Pengaruh signifikan per sektor dan arahnya bergantung pada jenis industri dan letak dilaksanakannya kegiatan operasional perusahaan. Walaupun kantor pusat terserang bencana banjir, namun selama kantor atau pabrik tempat melakukan 
kegiatan operasional aman, maka saham tidak berisiko terpengaruh.

\subsection{Saran}

Berdasarkan hasil penelitian di atas, peneliti ingin memberikan sejumlah masukan berkaitan dengan datangnya bencana banjir di Jakarta selanjutnya:

- Bagi investor untuk mempelajari pola banjir di Jakarta. Peneliti menyarankan agar pada saat awal tahun yaitu sekitar bulan Januari-Februari, investor membeli kepemilikan saham property atau trade karena harganya sedang jatuh di bulan Januari dan Februari dimana pada bulanbulan tersebut sangat rentan banjir. Sehingga investor akan mendapatkan keuntungan yang tinggi setelah melewati bulan Februari karena harganya akan naik. Sebaliknya, investor disarankan untuk menjual saham-saham di bidang barang konsumsi pada bulan Januari-Februari karena harganya akan melonjak di bulanbulan rawan banjir tersebut.

- Bagi manajer/direktur di perusahaanperusahaan perdagangan, jasa, dan investasi untuk lebih berhati-hati memasuki bulan Januari dan segera mencari cara untuk menghindari risiko yang dapat ditimbulkan oleh datangnya bencana banjir. Sementara pada perusahaan-perusahaan barang konsumsi, melihat tren melonjaknya return saham pada periode banjir, agar dapat memperbanyak kuantitas produksi untuk keuntungan yang lebih maksimal.

- Bagi peneliti selanjutnya dapat menggunakan bencana alam lainnya dan lokasi bencana alam yang lebih bervariasi. 
Analisis Pengaruh Bencana... (Evelyn Natasha dan Sumani)

\section{DAFTAR PUSTAKA}

Agusta, Rendra. 2013. Kisah Banjir dari Taruma Sampai Jakarta, Menjadi Trauma Jakarta. Retrieved Januari 18, 2013, dari http://sejarah.kompasiana.com/2013/01/18/kisah-banjir-dari-taruma-sampaijakarta-menjadi-trauma-jakarta-526470.html

Banjir Jakarta Hambat Perdagangan Saham. 2013, Januari 19. Harian Medan Bisnis. Retrieved dari http://www.medanbisnisdaily.com/news/read/2013/01/19/7975/banjir_jakarta_hambat_perdagangan _saham/

Lamb, Reinhold P. 1995. "An Exposure-Based Analysis of Property-Liability Insurer Stock Values Around Hurricane Andrew”. The Journal of Risk and Insurance, 62(1), 111-123.

Luo, Nannan. 2012. "The Impact of Natural Disasters on Global Stock Market: The Case of the Japanese 2011 Earthquake". A Master Research Project, 19-30.

Maierhofer, S. 2011. 5 Worst Disasters - How Did the Stock Market React? Retrieved dari http://www.etfguide.com/research/526/8/5-Worst-Disasters-How-Did-the-Stock-Market-React?/

Mania, Telo. 2013. (Misteri) Banjir Besar Lima Tahunan Jakarta. Retrieved Januari 16, 2013, dari http://metro.kompasiana.com/2013/01/16/misteri-banjir-besar-lima-tahunan-jakarta-525788.html

Wahyuni, Nurseffi Dwi dan Dian Ihsan. 2013. IHSG Cetak Rekor Baru Lagi di Tengah Banjir Jakarta. Retrieved Januari 18, 2013, dari http://bisnis.liputan6.com/read/491037/ihsg-cetak-rekor-baru-lagidi-tengah-banjir-jakarta

Worthington, A. C. dan Valadkhani, A. 2004. "Measuring the Impact of Natural Disasters on Capital Markets: An Empirical Application Using Intervention Analysis". Applied Economics, 36(19), 2177-2186.

Xie, Guo, dan Dang. 2011. "Impact of the 2008 Sichuan Earthquake on China's Stock Market: As an Example to the "Chenyu Plate" of China". World Rural Observations 2011, 3(1), 97-108.

Yamori, Nobuyoshi, dan Takeshi Kobayashi. 2002. "Do Japanese Insurers Benefit from A Catastrophic Event? Market Reactions to the 1995 Hanshin-Awaji Earthquake". Journal of the Japanese and International Economies, 16, 92-108.

www.bapepam.go.id

www.bi.go.id

www.bnpb.go.id

www.idx.co.id 